\title{
Saturation and its effect on the resilient modulus of a pavement formation material
}

\author{
LETISHA BLACKMORE*, CHRISTOPHER R. I. CLAYTON†, WILLIAM POWRIE $\$$, \\ JEFFREY A. PRIEST $\S$ and LOUISE OTTER\|
}

\begin{abstract}
This paper reports the effects of changing degree of saturation on the stiffness of a typical railway formation material. Material dynamically compacted to a target dry density over a range of water contents was cyclically loaded in triaxial and hollow cylinder apparatus. The results of both test types show the large effect of the degree of saturation on stiffness. In both the cyclic triaxial apparatus and the equivalent stress path in the cyclic hollow cylinder apparatus, the resilient modulus $\left(M_{\mathrm{R}}\right)$ increased considerably (from $\sim 36 \mathrm{MPa}$ to $\sim 467 \mathrm{MPa}$ ) as the degree of saturation fell. $M_{\mathrm{R}}$ at a water content of $7 \%$ (optimum under the $2.5 \mathrm{~kg}$ rammer) was approximately 1.5 times the near-saturated value (at $w=8 \%) . M_{\mathrm{R}}$ at the driest state tested $(w=4 \%)$ was approximately 6 times that measured for the near-saturated specimen. In the hollow cylinder apparatus, these trends were seen regardless of whether principal stress rotation was applied. The increase in $M_{\mathrm{R}}$ associated with decreasing water content is thought to result from an increase in matric suction. Increased scatter in $M_{\mathrm{R}}$ at higher suction may be the result of a more variable distribution of water within drier specimens. Comparison of suction stresses derived from the soil water retention curve with values back-calculated from cyclic triaxial testing suggests that useful estimates of railway formation resilient modulus, $M_{\mathrm{R}}$, may be made on the basis of measurements of matric suction.
\end{abstract}

KEYWORDS: laboratory tests; partial saturation; pavements \& roads; repeated loading; stiffness; suction

\section{INTRODUCTION}

The design of granular railway formations and flexible highway pavements requires, among other things, knowledge of the stiffness of the layers of which they, and the underlying formation, are composed. The subgrade formation must provide a stable platform throughout its life, without failure or excessive deformation resulting from traffic-induced stresses, or the effects of changing environmental factors such as rainfall and evapotranspiration.

In the construction of a railway (or highway) the various pavement materials will be carefully selected and compacted in the field at optimum water content to achieve a specified dry density. It is, however, inevitable that target water contents will not be achieved precisely and that further changes in water content will occur during the life of the track structure. These will modify the behaviour of the materials and under unfavourable conditions may lead to poor track performance. This paper explores the effect of applied stresses and as-compacted water content on the resilient modulus $\left(M_{\mathrm{R}}\right)$ of a typical formation material.

Manuscript received 2 March 2018; revised manuscript accepted 5 March 2019. Published online ahead of print 10 April 2019.

Discussion on this paper closes on 1 August 2020, for further details see p. ii.

Published with permission by the ICE under the CC-BY 4.0 license. (http://creativecommons.org/licenses/by/4.0/)

* Formerly University of Southampton, Southampton, UK; now University of Bath, Bath, UK.

$\dagger$ University of Southampton, Southampton, UK.

\$ University of Southampton, Southampton, UK

(Orcid:0000-0002-2271-0826).

$\S$ Formerly University of Southampton, Southampton, UK; now University of Calgary, Calgary, AB, Canada.

|| Formerly University of Southampton, Southampton, UK.

\section{MATERIAL TESTED}

The material tested was a compacted clayey sand. It contained $11 \%$ by weight of clay and was made up from three grades of sand (Leighton Buzzard fractions B (46.5\%), C $(9 \cdot 9 \%)$ and D (9.9\%)), Oakamoor HPF5 silt (20.8\%) and Hymod Prima ball clay $(12 \cdot 9 \%)$. The Hymod Prima ball clay (ECC, 2008) is commercially available and contains some quartz particles as well as clay. It was selected to represent sub-ballast layers typical of those used for new heavy-haul railway line construction, or for the upgrading of existing railway lines, such as the $580 \mathrm{~km}$ coal line in South Africa. It was termed material B by Gräbe \& Clayton (2009).

The results of previous studies using this material have been reported by Gräbe \& Clayton $(2009,2014)$, Otter et al. (2015) and Mamou et al. $(2017,2018)$. Table 1 compares plasticity test results (BS 1377 - part 4) for the material used in this study with those reported by Gräbe (2002) and Otter (2011).

In the field, during construction, the sub-ballast material is normally specified based on

(a) an acceptable particle size distribution

(b) compaction in the field at a moisture content close to the optimum water content (OMC), and

(c) achieving a dry density in the field greater than a specified value, based on the maximum dry density (MDD).

The OMC and MDD are determined in standard laboratory compaction tests as specified for example in the modified American Association of State Highway and Transportation Officials (AASHTO) T180 (AASHTO, 1993), ASTM D1557 (ASTM, 2007) and BS 1377-4 (BSI, 2012) $4 \cdot 5 \mathrm{~kg}$ rammer tests.

The South African Transnet S410 earthworks specification (Transnet, 2006) distinguishes between four formation layers (SSB, SB, A and B) and bulk earthworks. The four formation 
Table 1. Comparison of plasticity test results for material B fines with those reported by Gräbe (2002) and Otter (2011)

\begin{tabular}{l|c|c|c|c|c}
\hline Study & Plastic limit: \% & Liquid limit: \% & Plasticity index: \% & Clay content & Activity A \\
\hline Gräbe (2002) & 14 & 28 & 14 & 11 & 11 \\
Otter (2011) & 14 & 29 & 15 & 11 & $1 \cdot 4$ \\
Present study & 14 & 27 & 13 & 11 & $1 \cdot 2$ \\
\hline
\end{tabular}

layers decrease in density and stiffness from the top down (SSB to layer B) and, in common with highway pavements, are prescribed to have sufficient stiffness and thickness to support the rail track and ballast over the design life. The minimum densities to be achieved in the field (in terms of the maximum dry density in the modified AASHTO laboratory compaction test) are $98 \%, 95 \%, 93 \%$ and $90 \%$, respectively. Compaction water content in the field must be between $+1 \%$ and $-2 \%$ of the OMC in the same laboratory test.

\section{SPECIMEN PREPARATION}

The maximum dry density of material $\mathrm{B}$ was found from the BS $13774.5 \mathrm{~kg}$ rammer test to be $2 \cdot 26 \mathrm{Mg} / \mathrm{m}^{3}$ at an OMC of $4.8 \%$, giving a target dry density in the field for type A formation of $2 \cdot 15 \mathrm{Mg} / \mathrm{m}^{3}$ and for type $\mathrm{B}$ formation of $2 \cdot 10 \mathrm{Mg} / \mathrm{m}^{3}$. Gräbe (2002) and Otter (2011) previously used a dry density of $2 \cdot 10 \mathrm{Mg} / \mathrm{m}^{3}$ for their laboratory testing. This value was adopted in the present study as it allowed a reasonable range of specimen water content to be tested and permitted the results of the different studies to be compared. The compaction energy needed to achieve the target dry density at each water content was found by trial and error.

Dry material was thoroughly mixed with the appropriate amount of water, by hand, in a sealed plastic bag and allowed to equilibrate for a minimum of $24 \mathrm{~h}$. Solid $100 \mathrm{~mm}$ dia. specimens were compacted in a $204 \mathrm{~mm}$ high split mould, in five layers, using a pre-determined number of blows per layer. To improve axial uniformity the centres of the hollow cylinder apparatus (HCA) specimens were drilled out in two stages by hand using a wood auger, with an initial $30 \mathrm{~mm}$ dia. subsequently increased to $60 \mathrm{~mm}$ (the final internal diameter).

\section{APPARATUS AND INSTRUMENTATION}

The cyclic stiffness of a pavement or granular layer is an important parameter in the design of roads, runways and railways. Termed the 'resilient modulus', $M_{\mathrm{R}}$, it is used as both a long-term and short-term performance prediction parameter (Khoury \& Zaman, 2004). It is strongly affected by a number of factors, including material type, soil physical state (e.g. water content), normal effective stress, octahedral shear stress and stress history (e.g. type of loading and number of cycles of loading) (Li \& Selig, 1996; Gräbe \& Clayton, 2009). The suggestion that a single value of $M_{\mathrm{R}}$ might be used in flexible highway pavement design (AASHTO, 1993) has led to increased research (Lekarp et al., 2000; Ceratti et al., 2004; Ooi et al., 2004; Liang et al., 2008; Thom et al., 2008; Cary \& Zapata, 2011; Ng et al., 2013; Salour \& Erlingsson, 2015) on the effect of a number of these factors on $M_{\mathrm{R}}$. Given the number of variables affecting $M_{\mathrm{R}}$ and their often wide ranges, complex test programmes are necessary to determine the likely variability of resilient modulus in any given project.

The cyclic triaxial apparatus (CTX) was adopted for this research. It has become increasingly used in advanced testing of pavement materials (Harrigan, 2004) and in research studies on the effect of water content on $M_{\mathrm{R}}$ (Cary \& Zapata,
2011; Ng et al., 2013; Salour \& Erlingsson, 2015). The CTX readily enables a large number of specimens to be tested (Brown, 1996) so that the effects of cyclic loading of varying magnitudes, under a range of mean effective stresses, can be determined. However, the principal stress rotation (PSR) induced by a passing train (Powrie et al., 2007) cannot be applied (Hight \& Leroueil, 2003). Therefore, parallel tests were also conducted using a cyclic HCA (Gräbe \& Clayton, 2009).

To ensure representative behaviour in an element test the minimum specimen dimension should not be smaller than the shear band thickness. The shear band thickness for granular materials has been estimated from laboratory observations as 10 times the maximum grain size (Roscoe, 1970; Muhlhaus \& Vardoulakis, 1987) and as 7-8 times the mean grain size by Oda \& Kazama (1998) from X-ray image analysis. The hollow cylinder specimens had a wall thickness of $20 \mathrm{~mm}$, more than 10 times the $1.18 \mathrm{~mm}$ maximum particle size, allowing representative testing.

Because of the effect of suction (Otter et al., 2015) high stiffness was expected even at the low net normal stresses that were to be applied. Therefore, to avoid bedding errors, specimens were fitted with local linear variable differential transformers (LVDTs) to measure radial and vertical strains over the middle third of the specimens. A detailed description of the LVDT set-up in the HCA is given by Gräbe \& Clayton (2009). The use of local strain instrumentation was justified by the test results, global axial strain measurements being approximately 1.5 to 2 times the local strain measurements at OMC, and up to 7 times for drier, stiffer specimens tested in the CTX.

No pore water or air pressure measurements were made as the majority of the specimens were tested unsaturated. Measurement of pore pressures would have required slower rates of testing and the deployment of a tensiometer on the mid-plane. To mimic field conditions specimens were tested drained throughout - that is, the specimens were mounted on initially dry, low-air-entry porous stones and the air-filled back-pressure connection was vented to the atmosphere in a temperature-controlled room at $20^{\circ} \mathrm{C}$. The matric suction could not therefore be controlled or measured during testing, but the pore air pressure was approximately atmospheric.

\section{LOADING SEQUENCES}

As noted above, $M_{\mathrm{R}}$ depends on several factors. The cyclic triaxial and hollow cylinder testing reported in this paper was used to investigate the effects of net normal stress, cyclic deviatoric stress and PSR on stiffness, for a single material, at a single dry density, and a range of specimen water contents.

Pavement materials operate at shallow depths. Overburden pressure is low and (relatively) large transient and cyclic normal and shear stresses are applied by the traffic, along with significant PSR. Typical confining pressures of 20, 40 and $100 \mathrm{kPa}$ have been suggested for railway subgrade testing by Shahu et al. (2000), and in most of the pavement structure they can be expected to be less than $35 \mathrm{kPa}$ (Miller et al., 2000). 
Network Rail (2005) uses the repeated load triaxial test apparatus to measure the undrained modulus of poorly performing subgrade, under a $30 \mathrm{kPa}$ confining stress and a deviator stress of $30 \mathrm{kPa}$. However, this does not reflect the effects of different in situ depths or axle load variations.

The stress sequences applied during the CTX testing reported in this paper were based on the harmonised test method for flexible pavements as specified for granular subgrade material (Harrigan, 2004) following the recommendations of the National Cooperative Highway Research Program (NCHRP) project 1-28A, in which several AASHTO testing approaches were combined (harmonised). To cover the relevant ranges of the variables affecting $M_{\mathrm{R}}$, each specimen was compacted at a target water content, $w$, before being subjected to a test sequence consisting of 20 loading stages as shown in Table 2. Each loading stage was conducted at one of five confining (cell) pressures $\left(p_{\mathrm{o}}=15\right.$, $30,40,55$ or $85 \mathrm{kPa}$ ), and for each confining pressure, deviator stress ratios $\left(q_{\mathrm{cyc}} / p_{\mathrm{o}}\right)$ of $0 \cdot 5,1 \cdot 0,2 \cdot 0$ or 3.0 were applied, giving 20 stages in all. A minimum deviatoric stress $\left(q_{\min }\right)$ of $20 \%$ of the confining pressure was maintained throughout cycling, to ensure good contact between the specimen and the apparatus.

Taking stage number 3 in Table 2 as an example, the confining stress (cell pressure) was first increased from $30 \mathrm{kPa}$ (applied during stage number 2) to $40 \mathrm{kPa}$. The minimum deviatoric stress was $0 \cdot 2 \times 40 \mathrm{kPa}=8 \mathrm{kPa}$. For the desired cyclic stress ratio $\left(q_{\text {cyc }} / p_{\mathrm{o}}\right)$ of $0 \cdot 5$, the required cyclic deviatoric stress range $\left(q_{\text {cyc }}\right)$ was $20 \mathrm{kPa}$. One hundred cycles of sinusoidal deviatoric stress were applied to the specimen, between $8 \mathrm{kPa}$ and $28 \mathrm{kPa}$, about a cyclic stress datum of $18 \mathrm{kPa}$. The deviatoric stress was representative of the applied vertical stress from a passing train bogie, although it was applied at a somewhat slower rate, with a frequency in the CTX of $0.5 \mathrm{~Hz}$.

Figure 1 shows total stress paths in the $p-q$ plane during sinusoidal deviatoric stress cycling for the CTX test loading sequence in Table 2. The filled circular markers show the minimum stress points $\left(q_{\min }\right)$ for each of the five stress paths, resulting from the application of the cell pressure $(15,30,40$, 55 or $85 \mathrm{kPa}$ ) and a deviatoric stress of $20 \%$ of that cell

Table 2. CTX loading sequences based on the NCHRP project 1-28A - granular subgrade material test plan

\begin{tabular}{l|c|c|c|c}
\hline $\begin{array}{l}\text { CTX } \\
\text { loading } \\
\text { sequence }\end{array}$ & $\begin{array}{c}\text { Confining } \\
\text { pressure, } \\
p_{\mathrm{o}}: \mathrm{kPa}\end{array}$ & $\begin{array}{c}\text { Cyclic } \\
\text { stress ratio } \\
\left(q_{\text {cyc }} / p_{\mathrm{o}}\right)\end{array}$ & $\begin{array}{c}\text { Cyclic } \\
\text { stress range, } \\
q_{\text {cyc }}: \mathrm{kPa}\end{array}$ & $\begin{array}{c}\text { Cyclic } \\
\text { stress } \\
\text { datum: } \mathrm{kPa}\end{array}$ \\
\hline 1 & 15 & $0 \cdot 5$ & $7 \cdot 5$ & $6 \cdot 8$ \\
2 & 30 & $0 \cdot 5$ & 15 & $13 \cdot 5$ \\
3 & 40 & $0 \cdot 5$ & 20 & $18 \cdot 0$ \\
4 & 55 & $0 \cdot 5$ & $27 \cdot 5$ & $24 \cdot 8$ \\
5 & 85 & $0 \cdot 5$ & $42 \cdot 5$ & $38 \cdot 3$ \\
6 & 15 & $1 \cdot 0$ & 15 & $10 \cdot 5$ \\
7 & 30 & $1 \cdot 0$ & 30 & $21 \cdot 0$ \\
8 & 40 & $1 \cdot 0$ & 40 & $28 \cdot 0$ \\
9 & 55 & $1 \cdot 0$ & 55 & $38 \cdot 5$ \\
10 & 85 & $1 \cdot 0$ & 85 & $59 \cdot 5$ \\
11 & 15 & $2 \cdot 0$ & 30 & $18 \cdot 0$ \\
12 & 30 & $2 \cdot 0$ & 60 & $36 \cdot 0$ \\
13 & 40 & $2 \cdot 0$ & 80 & $48 \cdot 0$ \\
14 & 55 & $2 \cdot 0$ & 110 & $66 \cdot 0$ \\
15 & 85 & $2 \cdot 0$ & 170 & $102 \cdot 0$ \\
16 & 15 & $3 \cdot 0$ & 45 & $25 \cdot 5$ \\
17 & 30 & $3 \cdot 0$ & 90 & $51 \cdot 0$ \\
18 & 40 & $3 \cdot 0$ & 120 & $68 \cdot 0$ \\
19 & 55 & $3 \cdot 0$ & 165 & $93 \cdot 5$ \\
20 & 85 & $3 \cdot 0$ & 255 & $144 \cdot 5$ \\
\hline & & & &
\end{tabular}

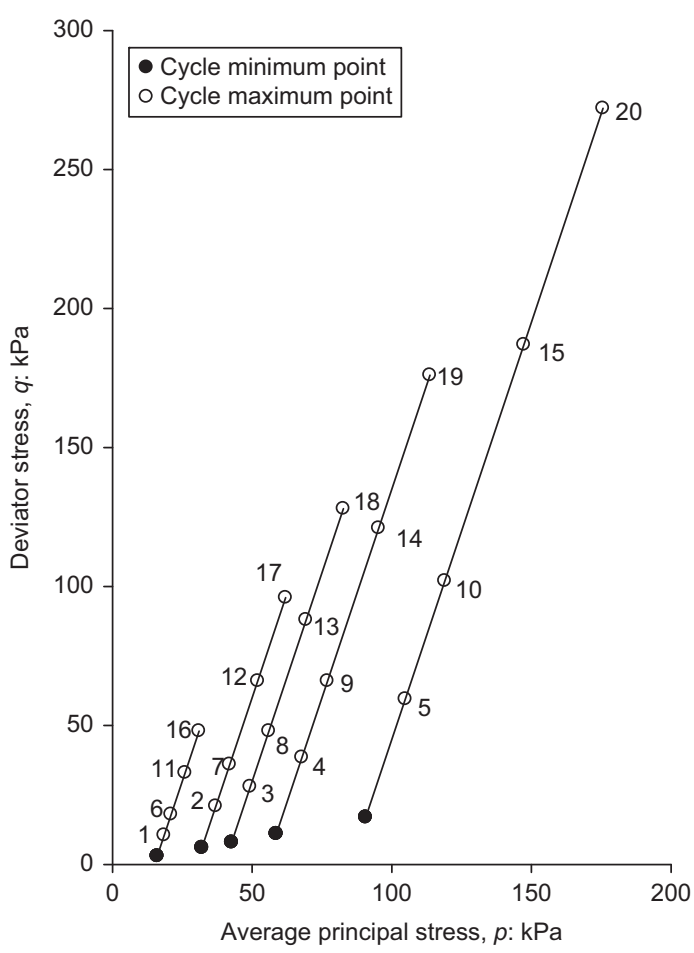

Fig. 1. Total stress paths during sinusoidal deviatoric stress cycling of cyclic triaxial test specimens

pressure. The open, numbered markers represent the maximum stresses during cycling for each of the loading stages in Table 2, which had cyclic stress ratios of $0 \cdot 5,1 \cdot 0,2 \cdot 0$ and $3 \cdot 0$. No pre-conditioning was applied as this is considered unnecessary when local strain measurements are made (Nazarian et al., 1996) and may result in the underestimation of $M_{\mathrm{R}}$ (Cerni et al., 2015).

Figure 2 shows typical CTX results during cycling for loading sequence number 7. Fig. 2(a) shows the development of global and average local vertical strain over 100 cycles at $0 \cdot 5 \mathrm{~Hz} . M_{\mathrm{R}}$ was calculated using the average of the recoverable local strain measurements made on diametrically opposite sides of the specimen unless stated otherwise. Deviator stress is plotted against vertical strain for cycles 1-5 and cycles 95-100 in Fig. 2(c). The straight line between the minimum and maximum points of cycle 100 indicates the basis of calculating resilient modulus, which is the slope of this line. Fig. 2(b) shows the total stress path under which the specimen was loaded cyclically.

The preparation of specimens and the stress paths applied in the HCA were broadly similar to those in the CTX.

(a) Specimens were prepared by compaction at a range of water contents to a target dry density of $2 \cdot 10 \mathrm{Mg} / \mathrm{m}^{3}$.

(b) The expected total stress path experienced by a representative element in the track foundation was applied.

(c) Matric suction was not measured and it was assumed that there was negligible pore air pressure during cycling; thus the net normal stress was equated to the applied total stress.

The effect of PSR on the measured resilient modulus was investigated by applying stages of loading with and without PSR. The cyclic stresses applied by Gräbe (2002) to simulate train-induced stresses were used during this study, to check 


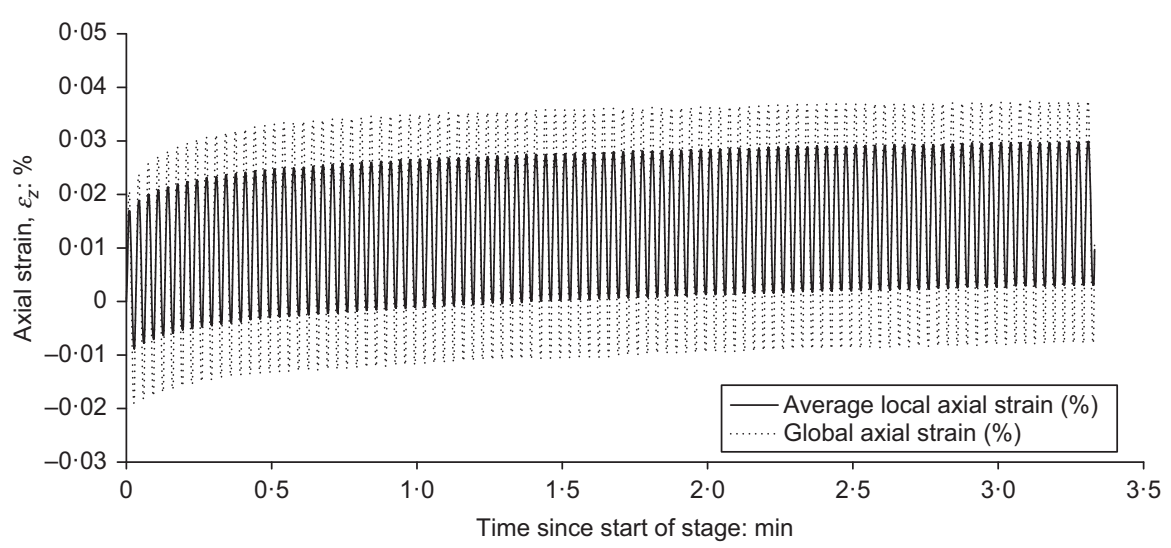

(a)

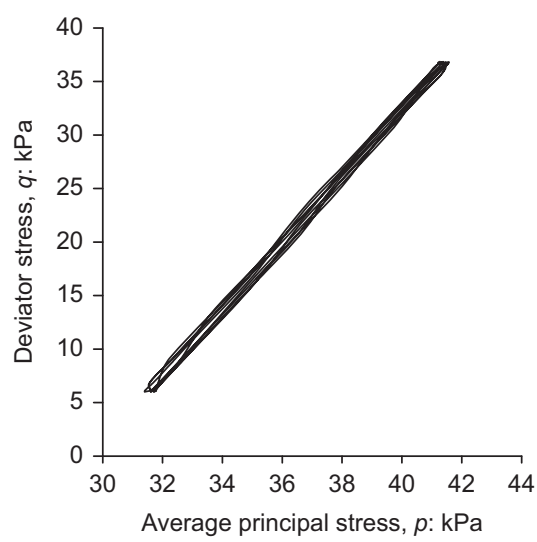

(b)

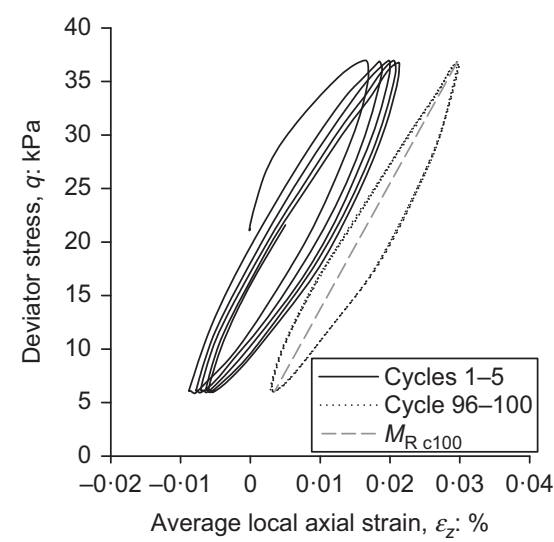

(c)

Fig. 2. Typical CTX results during cycling. (a) Development of global and local strains with time when loaded at 30 cycles/min. (b) Deviator stress, $q$, plotted against average total principal stress, $p$. (c) Deviator stress, $q$, as a function of vertical local strain, for selected cycles, showing calculation of $M_{\mathrm{R}}$

repeatability. Fig. 3 shows the two cyclic stress paths in terms of the applied stresses.

(a) In stress path 1 (SP1), the specimen was subjected to a cyclic axial (deviatoric) stress while the inner and outer cell pressures were held constant. No torsional load was applied so that there was no shear stress on the horizontal plane of the specimen, equivalent to loading in the CTX (sequence 7).

(b) In stress path 2 (SP2), the specimen was subjected to both cyclic deviatoric and cyclic torsional loading, thus inducing PSR. The inner and outer cell pressures were held constant and the cyclic rotational loading was $90^{\circ}$ out of phase with the cyclic deviator stress.

Because of the added complexity of torsional loading, a more restricted set of loading conditions was applied during HCA testing. An average confining pressure, $p_{\mathrm{o}}$, of $30 \mathrm{kPa}$ was selected to represent the pressures due to self-weight in a typical railway formation following Miller et al. (2000) and Shahu et al. (2000). A constant ratio of cyclic deviatoric stress $\left(q_{\text {cyc }}\right)$ to confining stress $\left(p_{\mathrm{o}}\right)$ of 1.0 was adopted in the HCA tests, as in sequence number 7 of the CTX testing (see Table 2). This was selected to be well below the expected failure stress ratio for materials compacted in a well-designed pavement.

The frequency of cycling applied in the HCA was $0.017 \mathrm{~Hz}$ (a period of $1 \mathrm{~min}$ ), much slower than applied in the CTX $(0.5 \mathrm{~Hz})$ and expected in the field, which might be up to at least $3 \mathrm{~Hz}$ for a high-speed railway $(3 \cdot 26 \mathrm{~Hz}$ being the vehicle passing frequency for a Valero train having an axle spacing of $2.5 \mathrm{~m}$ travelling at $80 \mathrm{~m} / \mathrm{s}$; (Milne et al., 2017)), or $13 \mathrm{~Hz}$ if individual wheel loading dominates. Limitations of data acquisition and control software prevented faster cycling in the HCA. The lower rate of cycling is likely to have reduced any build-up of excess pore air pressures or pore water pressures and consequent changes in net normal stress and matric suction. The influence of the slower testing rate on the measured resilient modulus was considered small based on comparisons of $M_{\mathrm{R}}$ measured in the HCA and CTX. A discussion of the influence of cyclic loading frequency and drainage conditions is given in Mamou et al. (2017).

Each of the HCA tests consisted of four phases. First, an isotropic confining stress of $30 \mathrm{kPa}$ was applied to equilibrate the specimen under in situ stress conditions. This was followed by three cyclic loading phases. Phases 1 and 3 applied 500 cycles of SP2 (no PSR, see above). Phase 2 applied 1000 cycles of SP1 (with PSR), except in test HCA + 0v2 for which the stress path order was changed (nl. stress path version 2 (v2)). This approach was adopted to allow an assessment of the effects of staging sequence (see Table 3). The first part of each test name (e.g. 'HCA' or ' $\mathrm{CTX')} \mathrm{denotes} \mathrm{the} \mathrm{apparatus} \mathrm{used} \mathrm{to} \mathrm{obtain} \mathrm{the} \mathrm{data.}$ This is followed by a number (e.g. '-3') denoting the specimen's water content relative to optimum. The stress path adopted for the majority of testing was termed 'version 1' (or ' $\mathrm{v} 1$ ') leading to a test name such as HCA- $1 \cdot 7 \mathrm{v} 1$. Other test variants (v0 and v2) examined, for example, the effect of test stage sequences. 


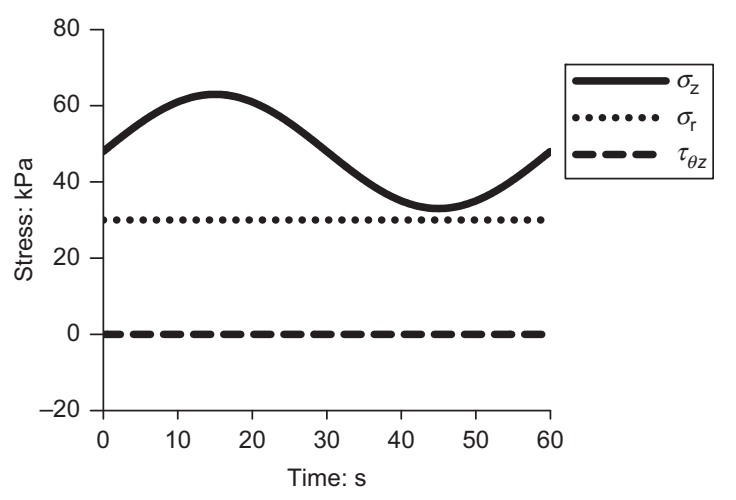

(a)

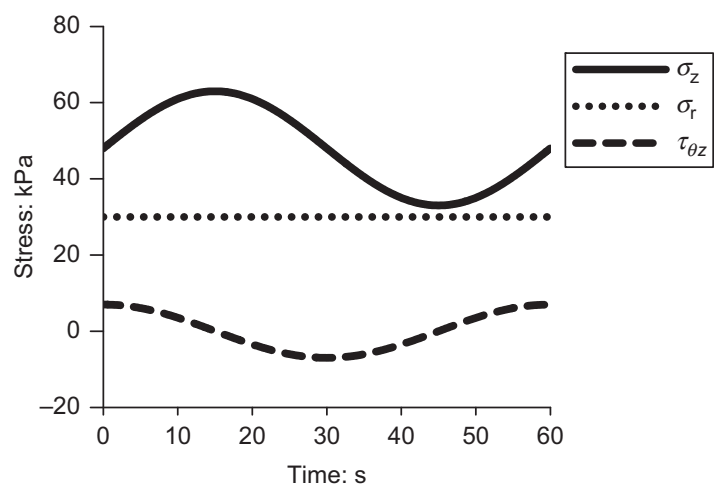

(b)

Fig. 3. Cyclic stress paths applied in the HCA in terms of the applied stresses $\sigma_{z}, \sigma_{\mathrm{r}}=\sigma_{\theta}$ and $\tau_{\theta z}$ to investigate the effect of PSR on $M_{\mathrm{R}}$ (redrawn from Gräbe (2002)). (a) SP1 without PSR and (b) SP2 with PSR

Table 3. Cyclic loading with and without PSR used in the HCA testing

\begin{tabular}{|c|c|c|c|}
\hline \multirow[t]{2}{*}{ Test name } & \multicolumn{3}{|c|}{ HCA loading sequence } \\
\hline & $\begin{array}{c}\text { Cyclic test } \\
\text { phase }\end{array}$ & $\begin{array}{l}\text { Cyclic stress } \\
\text { path }\end{array}$ & $\begin{array}{c}\text { Number of } \\
\text { cycles }\end{array}$ \\
\hline \multirow[t]{3}{*}{$\mathrm{HCA}+0 \mathrm{v} 1$} & 1 & SP2 & 500 \\
\hline & 2 & SP1 & 1000 \\
\hline & 3 & SP2 & 500 \\
\hline \multirow[t]{3}{*}{$\mathrm{HCA}+0 \mathrm{v} 2$} & 1 & SP1 & 500 \\
\hline & 2 & SP2 & 1000 \\
\hline & 3 & SP1 & 500 \\
\hline \multirow[t]{3}{*}{ HCA-1v1 } & 1 & SP2 & 500 \\
\hline & 2 & SP1 & 1000 \\
\hline & 3 & SP2 & 500 \\
\hline \multirow[t]{2}{*}{$\mathrm{HCA}-1 \cdot 7 \mathrm{v} 1$} & 1 & SP2 & 500 \\
\hline & 2 & SP1 & $540^{*}$ \\
\hline \multirow[t]{3}{*}{ HCA-2v1 } & 1 & SP2 & 500 \\
\hline & 2 & SP1 & 1000 \\
\hline & 3 & SP2 & $120^{*}$ \\
\hline \multirow[t]{3}{*}{ HCA-3iv1 } & 1 & SP2 & 500 \\
\hline & 2 & SP1 & 1000 \\
\hline & 3 & SP2 & 500 \\
\hline \multirow[t]{3}{*}{ HCA-3iiv1 } & 1 & SP2 & 500 \\
\hline & 2 & SP1 & 1000 \\
\hline & 3 & SP2 & 500 \\
\hline \multirow[t]{3}{*}{$\mathrm{HCA}+1 \mathrm{v} 1$} & 1 & SP2 & 500 \\
\hline & 2 & SP1 & 1000 \\
\hline & 3 & SP2 & 500 \\
\hline
\end{tabular}

Note: During PSR, confining stress $=30 \mathrm{kPa}$, deviatoric stress amplitude $=7 \mathrm{kPa}$, datum $=0 \mathrm{kPa}$, phase angle $=90^{\circ}$.

*Test interrupted.

\section{Loading rate and drainage}

The resilient modulus, $M_{\mathrm{R}}$, of each specimen was determined from the average strains measured in both the CTX and the HCA from the last five cycles up to the 100th cycle of deviatoric stress loading. However, the cyclic frequency used in the CTX was $0.5 \mathrm{~Hz}$ in line with the NCHRP project $1-28 \mathrm{~A}$ testing protocol, whereas in the HCA a lower frequency of one cycle per minute $(0.0167 \mathrm{~Hz})$ was necessary to facilitate data logging and maintain test control.

The time required between the different test stages is not prescribed in the NCHRP project 1-28A. Initially, testing was conducted allowing a rest period of $5 \mathrm{~min}$ following each cell pressure increase and $10 \mathrm{~min}$ following each cell pressure decrease (from $85 \mathrm{kPa}$ to $15 \mathrm{kPa}$ at the beginning of stages 6 , 11 and 16). For each loading stage, the deviator stress datum $\left(q_{\text {min }}+q_{\text {cyc }} / 2\right)$ was initially changed to its next value over a period of $2 \mathrm{~min}$, but this was adjusted after it was found that this gave inadequate time for pore pressure dissipation in specimens with higher water contents. Subsequent testing applied cell pressure changes at a rate of $2 \mathrm{kPa} / \mathrm{min}$.

\section{Stress history effects}

The stiffness of a railway formation, as with soil, is known to be influenced by its stress history. Gräbe (2002) explored the effect of overconsolidation ratio (OCR) on saturated formation material consolidated from a slurry. $\mathrm{He}$ found that $M_{\mathrm{R}}$ increased by about $20 \%$ when the OCR was increased from 15 to 25 , and that the application of PSR had relatively little influence (a few per cent) on the effect of OCR.

In the tests reported in this paper the specimens were for the most part unsaturated and dynamically compacted, and therefore did not require pre-conditioning by overconsolidation. However, the effect of multi-staging in the CTX needed to be assessed since formation materials cannot be assumed to behave elastically; hence stiffness cannot be assumed to be solely dependent on material type, water content and stress state. The effect of CTX multi-staging on the measured stiffness was investigated by changing the loading sequence from that described in Table 2. These tests showed that the sequence of loading stages did not significantly influence the measured values of $M_{\mathrm{R}}$ provided vertical strains remained below $5 \%$.

\section{TYPICAL RESULTS}

Figure 2 shows typical CTX results during cycling a specimen with a water content of $7 \%$ under loading sequence 7. Fig. 2(a) shows the development of global (external) and local strains during the application of 100 cycles of sinusoidal deviatoric stress loading. The significant differences in amplitude between these two sets of results suggest that resilient modulus must be measured using local strain instrumentation. Fig. 2(b) shows the stress path during cycling. Fig. 2(c) shows deviatoric stress plotted as a function of local vertical strain for the first five and the last five loading cycles. Despite the hysteresis, 100 cycles were sufficient to produce a stable (resilient) stress-strain behaviour in this material, at these stress levels. The slope of the straight line joining the two ends of the final hysteretic loop shows the position at which the resilient modulus was measured.

Figure 4 shows resilient modulus measured in the CTX apparatus as a function of confining pressure, $p_{\mathrm{o}}$ (Fig. 4(a)), and maximum deviator stress, $q_{\max }$ (Fig. 4(b)), for water contents between 4 and $8 \%$. Reducing the water content has the dominant effect although increases in $p_{\mathrm{o}}$ and $q_{\max }$ also lead to more modest increases in $M_{\mathrm{R}}$. 


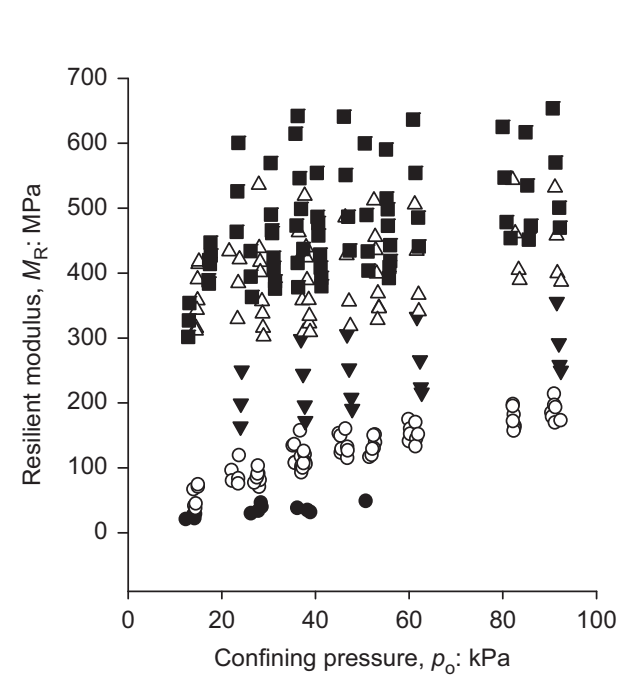

(a)

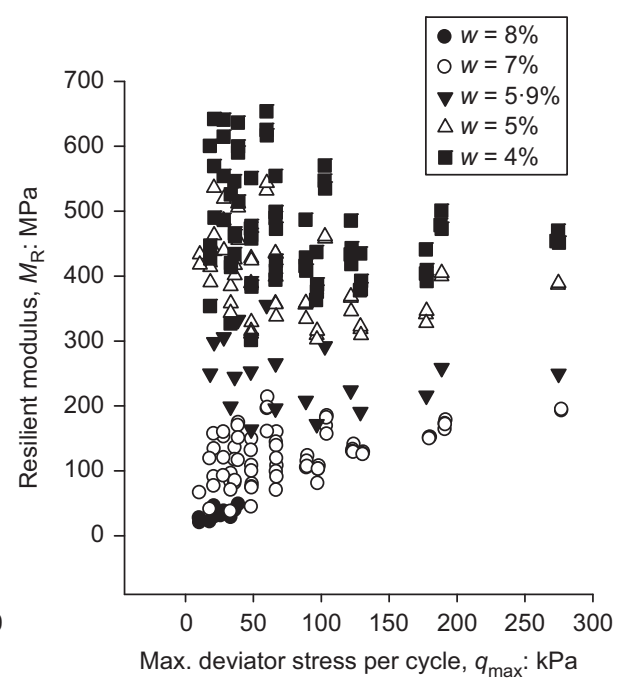

(b)

Fig. 4. Measured resilient modulus from CTX tests for specimens at various water contents as a function of (a) of confining stress, $p_{0}$, and (b) maximum deviator stress, $q_{\max }$

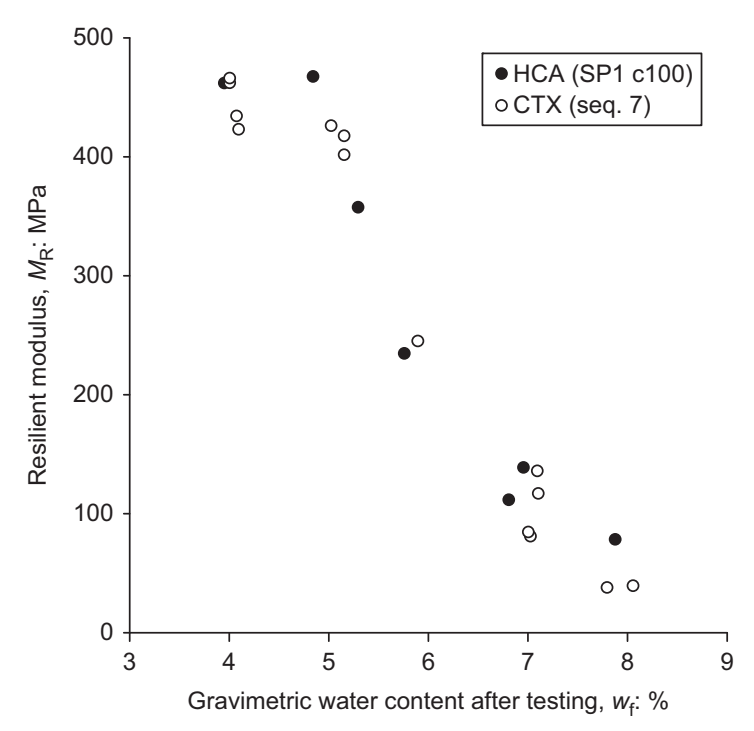

Fig. 5. Comparison of resilient modulus measured in the cyclic triaxial test and in the HCA under CTX conditions

\section{DISCUSSION}

Resilient moduli $\left(M_{\mathrm{R}}\right)$ obtained from the cyclic triaxial (CTX) and hollow cylinder (HCA) tests on unsaturated clayey sand reported in this paper are broadly in line with the relatively few results reported in the literature for low-plasticity soils. $M_{\mathrm{R}}$ values for specimens with a water content of $7 \%$ and a dry density of $2 \cdot 10 \mathrm{Mg} / \mathrm{m}^{3}$ were between 110 and $150 \mathrm{MPa}$, similar to those back-figured from field monitoring in South Africa reported by Gräbe et al. (2005) and Priest et al. (2010). The track subgrade resilient modulus design target value adopted for this material in South Africa is typically $100 \mathrm{MPa}$ (Lourens \& Maree, 1997; Gräbe, personal communication, 2017).

\section{Effect of apparatus type}

Figure 5 compares resilient moduli measured at the end of load sequence number 7 in the CTX at a range of water contents with those measured in the HCA under cyclic triaxial conditions (SP1 at cycle 100). Despite some scatter the results show reasonable agreement between the two different methods over the range of water contents tested.
A smaller difference between the values of axial strain measured on radially opposite sides of the specimen was seen in the HCA than in the CTX. This could be a result of differences between the load cell arrangement and specimen fixity in each apparatus (Baldi et al., 1988; Gasparre et al., 2014). The HCA axial/torque load cell is integrated with the top cap fitted to the specimen to allow rotational loading, while the load cell in the CTX is not fixed to the top cap. The CTX load cell is integrated into a ram with hemispherical end placed onto a coned seating, such that a slight eccentricity of load onto the specimen top cap can be accommodated (Baldi et al., 1988; Gasparre et al., 2014).

\section{Effect of water content and degree of saturation}

The HCA and CTX measurements of stiffness $\left(M_{\mathrm{R}}\right)$ in general confirm the large effect of water content and degree of saturation (Fig. 5) on stiffness previously seen by Otter et al. (2015) at very small strains in resonant column (RCA) tests. Fig. 5 indicates a maximum resilient modulus in the order of $450 \mathrm{MPa}$ at water contents between 4 and $5 \%$ suggesting that stiffness of this material may peak or even decrease at water contents less than 5\%. At a water content of $8 \%$ (close to saturation) the measured resilient modulus in the CTX tests is approximately one order of magnitude lower than the maximum values. At low net normal stresses Otter and co-workers measured a tripling in $G_{0}$, from $\sim 50 \mathrm{MPa}$ to $\sim 150 \mathrm{MPa}$, as the degree of saturation reduced from near saturated to approximately $55 \%(w=5 \%)$. In the present study a decrease in water content resulted in an up to six-fold increase in $M_{\mathrm{R}}$ (Fig. 6) compared to the near-saturated value (at $w=8 \%$ ), although part of this increase may be a result of the higher strains in the HCA and CTX tests than in the RCA. The $M_{\mathrm{R}}$ value measured for the near-saturated specimen (at $w=8 \%$ ) of $\mathrm{HCA}+1 \mathrm{v} 1$ was selected as representative of the saturated response in the context of values from tests conducted by Gräbe (2002) on the same material prepared from slurry. The permanent strains, measured after 500 cycles on low-water-content specimens, were significantly smaller (approximately $0.002 \%$ for $w=4 \%$ and $w=5 \%$ ) than at a higher water content $(0 \cdot 17 \%$ at $\mathrm{OMC}=7 \%)$. For comparison, the $G_{0}$ values reported by Otter et al. (2015) were measured at shear strains of less than $0 \cdot 001 \%$.

The $M_{\mathrm{R}}$ increased considerably, from 36.4 to $467 \mathrm{MPa}$ (Fig. 5), as the degree of saturation decreased from 85 to $45 \%$ 


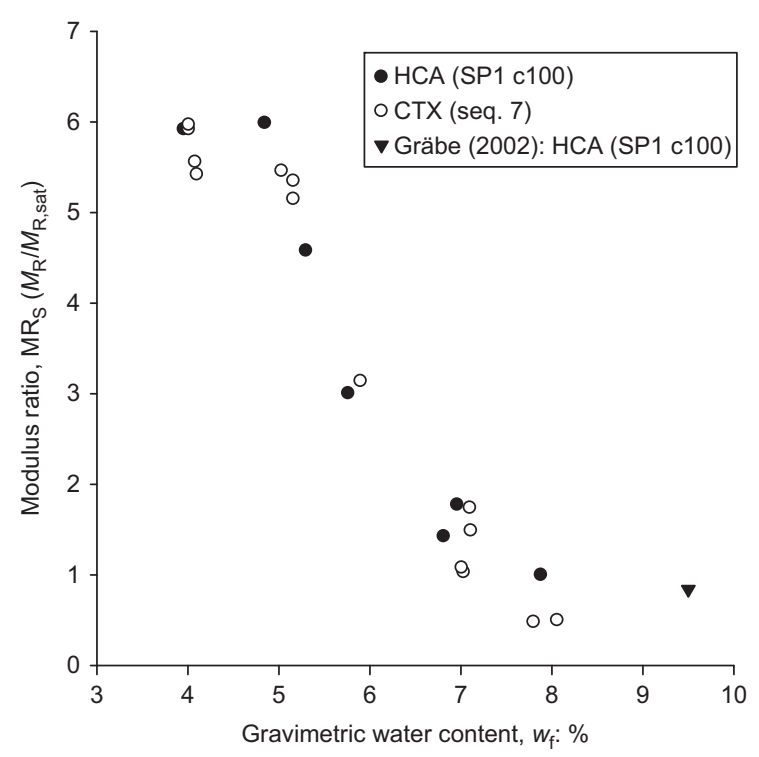

Fig. 6. Suction modulus ratio $\left(M R_{S}\right)$ indicating the relative change in $M_{\mathrm{R}}$ due to a change in water content (and associated suction) of the material. HCA and CTX $M_{\mathrm{R}}$ normalised by $M_{\mathrm{R} \text {,sat }}(\mathrm{HCA}+1 \mathrm{v} 1)$. Value from Gräbe (2002) included for comparison only

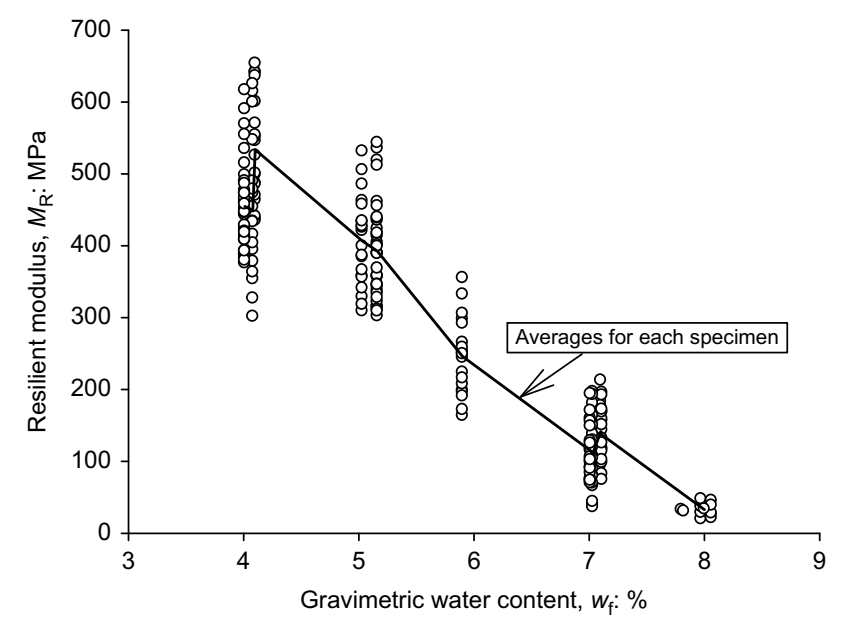

Fig. 7. Resilient modulus as a function of final water content, $w_{\mathrm{f}}$ for all tests and sequences

when measured in the CTX and equivalent HCA (SP1) tests carried out with $p_{\mathrm{o}}=q_{\mathrm{cyc}}=30 \mathrm{kPa}$ at different compaction water contents (between $w=8 \%$ and $w=4 \%$ ). The average $M_{\mathrm{R}}$ at optimum $(w=7 \%)$ was approximately 1.7 times the near-saturated value (at $w=8 \%$ ) from $\mathrm{HCA}$ test results. $M_{\mathrm{R}}$ at the driest state tested $(w=4 \%)$ was approximately 6 times the value measured for the near-saturated specimen. The scatter in $M_{\mathrm{R}}$ for all tests decreased significantly as the water content increased (Fig. 7). This is a result of a number of factors that affect $M_{\mathrm{R}}$ on this plot, which are discussed in the following sections. There was a significant proportional decrease in average resilient modulus as the water content increased, particularly from optimum $(7 \%)$ towards saturation.

\section{Effect of confining pressure $\left(\mathrm{p}_{o}\right)$ and cycliclmaximum (deviator stress $\left(\mathrm{q}_{\text {cyc }} / \mathrm{q}_{\max }\right.$ )}

Figure 4 shows the effects of confining pressure $\left(p_{\mathrm{o}}\right)$ and cyclic/maximum deviator stress $\left(q_{\text {cyc }} d q_{\text {max }}\right)$ on the resilient modulus, $M_{\mathrm{R}}$, measured during the 100th cycle of loading for different water contents. Confining pressures varied from
15 to $85 \mathrm{kPa}$, and cyclic deviator stresses from $7 \cdot 5$ to $255 \mathrm{kPa}$. Comparing the trends in the resilient moduli determined for specimens with $8 \%$ water content with those for specimens with lower water contents shows that although confining pressure and cyclic deviator stress have a significant effect on $M_{\mathrm{R}}$, the effect of water content (hence degree of saturation) dominates for water contents greater than $5 \%$. This is confirmed in Fig. 7.

In some cases, the stresses applied to the formation by traffic appear to have a more significant influence on the resilient modulus. Fig. 4(a) shows $M_{\mathrm{R}}$ as a function of $p_{\mathrm{o}}$ for water contents, $w_{\mathrm{f}}$. At a water content of $7 \%$ (optimum) there is a clear, non-linear trend of $M_{\mathrm{R}}$ increasing with $p_{\mathrm{o}}$. Although there appears to be a similar underlying trend at $4 \%$ water content, this is largely obscured by scatter in the data. This may be a result of inadequate instrument resolution at the very high specimen stiffnesses associated with small water contents. It could also be related to the water content within the sample becoming more variable (or random) at lower water contents as it relates to the small pore spaces (Alonso et al., 2013). Any effects of $q_{\text {cyc }}$ and $q_{\max }$ on $M_{\mathrm{R}}$ are obscured by this scatter in the data.

\section{Effect of permanent strain}

An increase in $M_{\mathrm{R}}$ with decreasing water content may have been to some extent the result of lower permanent strains, since the tests in the CTX and HCA were stress controlled. The permanent strains measured after 500 cycles were significantly smaller for low water content (approximately $0.002 \%$ for $w=4 \%$ and $w=5 \%$ ) than for higher water content specimens $(0 \cdot 17 \%$ at $\mathrm{OMC}=7 \%)$.

\section{Effect of drainage during cyclic loading}

All testing was carried out drained (for both air and water) by allowing the top and bottom pore pressure lines to drain to the atmosphere. It was assumed that the pore air pressure in the specimens remained at atmospheric $\left(u_{\mathrm{a}}=0\right)$, giving a net normal stress, $\sigma_{\mathrm{n}}=\sigma-u_{\mathrm{a}}$, equal to the applied total stresses. Variations in matric suction during cyclic loading were not assessed.

For specimens tested wet of optimum $(w=8 \%)$ and close to saturation $\left(S_{\mathrm{r}}>95 \%\right) \quad M_{\mathrm{R}}$ measured in the CTX was considerably lower (in the order of half) than measured in the HCA. This is thought to have been due to a build-up of excess pore pressure in the CTX, although in the absence of mid-plane pore pressure measurement this hypothesis could not be tested. In contrast, comparable values of $M_{\mathrm{R}}$ were obtained for unsaturated (lower water content) specimens tested in the CTX and the HCA after 100 cycles with $p_{\mathrm{o}}=q_{\mathrm{cyc}}=30 \mathrm{kPa}$, without PSR (Fig. 5).

\section{Effect of principal stress rotation}

The effect of PSR on the resilient modulus was investigated using the HCA, applying identical stages of normal stress loading with and without PSR as already described. The cyclic stresses used by Gräbe (2002) to simulate train loading were applied (Table 3).

Figure 8 shows the effects of water content (and inferred suction through the soil water retention curve (SWRC)) on the ratio of $M_{\mathrm{R}}$ measured, using the HCA, with PSR (SP2) and without PSR (SP1) $\left(\mathrm{MR}_{\mathrm{PSR}}=M_{\mathrm{R}, \mathrm{SP} 1} / M_{\mathrm{R}, \mathrm{SP} 2}\right)$, for each water content specimen as measured after 500 and 1000 cycles, respectively. The modulus ratio at OMC $(w=7 \%)$ was approximately $1 \cdot 15$, representing a $13 \%$ reduction in $M_{\mathrm{R}}$ when PSR was applied. Thus at OMC $M_{\mathrm{R}}$ will be slightly overestimated if measured in the CTX without PSR. Fig. 8 


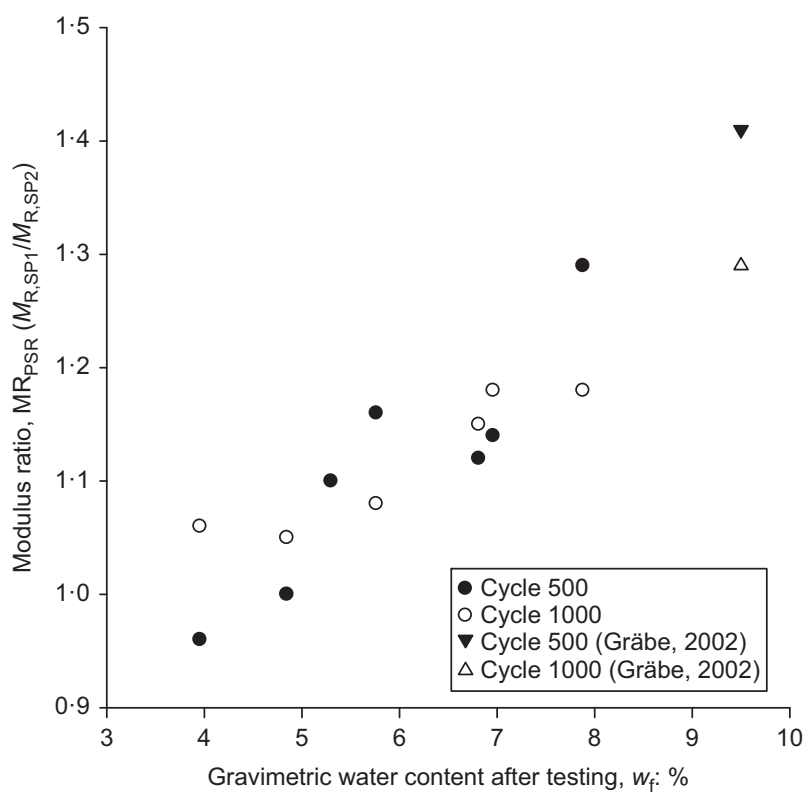

Fig. 8. Effect of PSR (SP2 in the HCA) on resilient modulus (e.g. $\mathrm{MR}_{\mathrm{PSR}, \mathrm{c500}}=M_{\mathrm{R}, \mathrm{SP1}, \mathrm{c500}} / M_{\mathrm{R}, \mathrm{SP2}, \mathrm{c500})}$ at different water contents (hence suctions)

shows that $\mathrm{MR}_{\mathrm{PSR}}$ decreases as the water content (and hence stiffness, $M_{\mathrm{R}}$ ) decreases. In practical terms, given the difficulties of measurement, the effect of PSR on the stiffness of unsaturated pavement formation can therefore reasonably be ignored for the typical load case considered.

\section{Effect of suction}

It is not possible to express the effective stress of an unsaturated soil in terms of its pore water pressure, or indeed any single parameter, because the pore water is discontinuous and the liquid and air phases of the pore fluid require (at least) two independent state variables. A number of simplified approaches to the determination of an equivalent effective stress for an unsaturated material have been proposed in recent years.

To assess the effect of suction on rail formation stiffness the 'suction stress' approach (Lu \& Likos, 2006; Lu et al., 2010) was adopted as follows.

(a) First, the matric suction or SWRC for material B was calculated from data presented by Otter (2011) using the curve fitting procedure by Fredlund \& Xing (1994), with their correction factor, $C(\psi)$.

(b) The suction stress $\left(\sigma_{\mathrm{s}}\right)$ was then obtained by multiplying the calculated matric suction by the effective degree of saturation (Alonso et al., 2013), to produce the suction stress characteristic curve (SSCC).

The SWRC, for the material B also tested in the present study, was derived by Otter (2011) using Chandler's filter paper method (Chandler et al., 1992). Otter (2011) carried out a large number of tests on material B. She found the air entry value and residual water content difficult to identify, which made determination of the inflexion point on the SWRC uncertain.

Otter (2011) fitted her SWRC data using Fredlund and Xing's (1994) equation

$$
\theta_{\mathrm{w}}=\frac{\theta_{\mathrm{s}}}{\left\{\ln \left[e+\left(\frac{\psi}{a}\right)^{n}\right]\right\}^{m}}
$$

with its correction factor

$$
\theta=\theta_{\mathrm{w}} C(\psi)
$$

where

$$
C(\psi)=\frac{\ln \left(1+\psi / \psi_{\mathrm{r}}\right)}{\ln \left[1+\left(1000000 / \psi_{\mathrm{r}}\right)\right]}
$$

$\theta_{\mathrm{w}}$ is the volumetric water content at matric suction, $\psi ; \theta_{\mathrm{s}}$ is the saturated volumetric water content (taken as $20.4 \%$ in this case); $e$ is Euler's number (2.71828); $\psi_{\mathrm{r}}$ is the residual matric suction; and determined the Fredlund and Xing variables as $a=150 \mathrm{kPa}, n=1 \cdot 1841$ and $m=0.92327$.

$\mathrm{Lu}$ et al. (2010) proposed that the suction stress, $\sigma_{\mathrm{s}}$, represents the contribution of suction (considered as particle contact level forces (Santamarina, 2003; Mitchell \& Soga, 2005) to the effective stress governing the shear strength of unsaturated soil. Here and in Otter et al. (2015) the concept has been extended to stiffness, relating the suction stress at any water content to the matric suction by the effective degree of saturation, $S_{\mathrm{e}}$, defined by $\mathrm{Lu}$ et $a l$. (2010) as

$$
\sigma_{\mathrm{s}}=-\frac{\theta-\theta_{\mathrm{r}}}{\theta_{\mathrm{s}}-\theta_{\mathrm{r}}}\left(u_{\mathrm{a}}-u_{\mathrm{w}}\right)=-S_{\mathrm{e}}\left(u_{\mathrm{a}}-u_{\mathrm{w}}\right)
$$

where $\theta$ is the volumetric water content; $\theta_{\mathrm{r}}$ is the residual volumetric water content; and $\theta_{\mathrm{s}}$ is the saturated volumetric water content.

The calculated SWRC for material B is shown as a dashed line in Fig. 9 for a dry density of $2 \cdot 1 \mathrm{Mg} / \mathrm{m}^{3}$ as determined previously by Otter (2011) and Otter et al. (2015) for the same material tested in this study. The matric suction varies from zero at saturation $(w=9 \cdot 8 \%)$ to approximately $800 \mathrm{kPa}$ at a water content of $4 \%$.

Otter (2011) identified the residual matric suction as $1500 \mathrm{kPa}$ at a water content of $3 \%$. The matric suction from the SWRC was multiplied by the effective degree of saturation, $S_{\mathrm{e}}$, to obtain the SSCCs. To assess the effect of the residual water content selected, the SSCC was also calculated

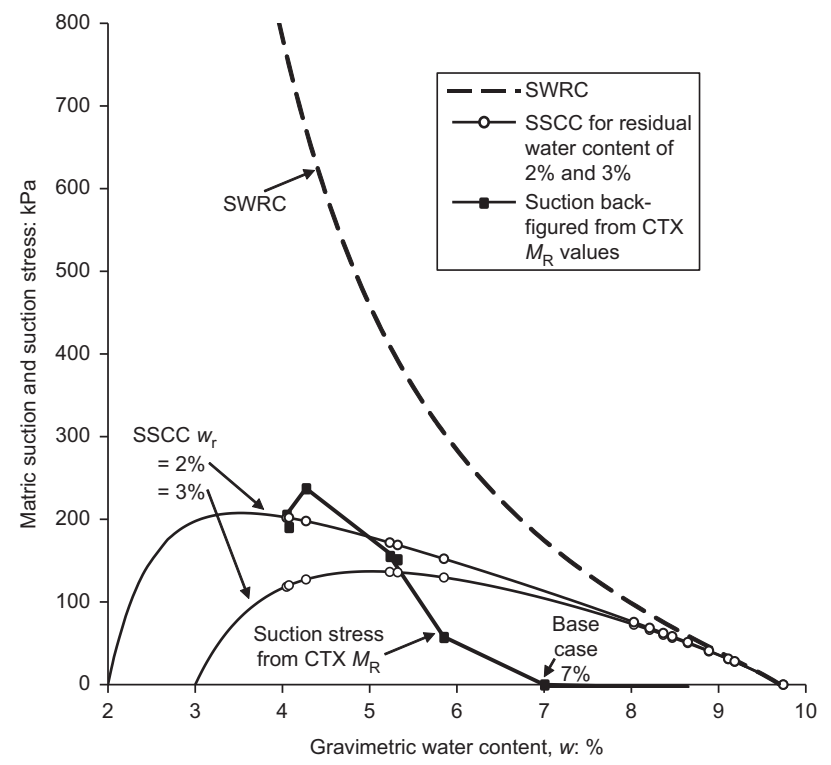

Fig. 9. Suction stress estimated from the SWRC for residual water contents of $2 \%$ and $3 \%$, compared with values back-calculated from cyclic triaxial $M_{\mathrm{R}}$ results for material $\mathrm{B}$ compacted at optimum water content $(\mathbf{7} \%)$ 
for a residual water content of $2 \%$. The SSCCs for the two residual water contents are shown by the thin full lines in Fig. 9. The suction stress $\left(\sigma_{\mathrm{s}}\right)$ is then added to the net normal stress $\left(\sigma_{\mathrm{n}}\right)$ to obtain the 'equivalent effective stress'. Note that a reduction in suction stress at low water contents, as seen in Fig. 9, can be expected in granular materials (Lu \& Likos, 2006), as the impact of the small amounts of water remaining becomes negligible as the soil dries.

The open circles superimposed on the SSCC curves represent the water contents and the calculated suction stresses, based on the SSCC, of the specimens tested in the CTX. For specimens with gravimetric water contents dry of optimum (in the range $4-5 \cdot 5 \%$ ) Fig. 9 shows that the suction stresses are expected to be between about 120 and $210 \mathrm{kPa}$. These are much greater than the net normal stresses of 15 to $85 \mathrm{kPa}$ imposed during testing, indicating the significance of suctions in increasing the resilient modulus. The group of results at water contents greater than $7 \%$ represents specimens made up at or wet of optimum, and close to saturation. The suction stresses calculated from the SSCC for gravimetric water contents between 8 and $9 \cdot 2 \%\left(S_{\mathrm{R}}\right.$ between $82 \cdot 1$ and $94 \cdot 5 \%$ ) range from approximately 50 to $70 \mathrm{kPa}$. However, it should be emphasised that the SSCC refers to specimens of the particular density for which the SWRC on which it is based applies.

Suction stresses $\left(\sigma_{\mathrm{s}}\right)$ were also back-calculated from the $M_{\mathrm{R}}$ results for specimens at different water contents using the approach suggested by Heath et al. (2004). Multi-variate linear regression analysis was applied to optimise the correlation between measured and calculated $M_{\mathrm{R}}$ for the OMC specimen according to the 'universal model' (Uzan, 1985; Lekarp et al., 2000) to determine the three parameters, $k_{1}, k_{2}$ and $k_{3}$, in equation (5)

$$
M_{\mathrm{R}}=k_{1} p_{\mathrm{a}}\left(\frac{\Theta}{p_{\mathrm{a}}}\right)^{k_{2}}\left(\frac{\tau_{\mathrm{oct}}}{p_{\mathrm{a}}}+1\right)^{k_{3}}
$$

where $\Theta$ is the bulk effective stress, the sum of the principal effective stresses $\left(\sigma_{1}^{\prime}+\sigma_{2}^{\prime}+\sigma_{3}^{\prime}\right) ; \tau_{\text {oct }}$ is the octahedral shear stress $\left(=(\sqrt{2} / 3)\left(\sigma_{1}^{\prime}-\sigma_{3}^{\prime}\right)\right.$ for triaxial compression; $p_{\mathrm{a}}$ is atmospheric pressure $(100 \mathrm{kPa})$; and $k_{1}, k_{2}, k_{3}$ are regression coefficients.

The back-calculation method uses the regression coefficients determined from the cyclic triaxial test on material compacted at OMC (in this case, 7\%) as the base case, given that this test was completed within the $5 \%$ vertical strain limit specified by Harrigan (2004). Equation (5) was then used to determine the mean principal stress $(p)$ required to obtain an $M_{\mathrm{R}}$ value in a test on a hypothetical base case specimen (OMC) equal to that measured in each of the unsaturated specimens. The suction stress for each unsaturated specimen was then calculated from the difference between this value of $p_{\mathrm{o}}$ and the value of $p_{\mathrm{o}}$ actually applied during the test. Twenty $M_{\mathrm{R}}$ values were determined from each of the CTX tests of which approximately $5 \%$ of the total of 200 measurements were excluded from the regression analysis as outliers. The results from the 'equivalent $M_{\mathrm{R}}$ ' approach are shown in Fig. 9 by filled square markers connected by straight lines.

In contrast to the suction stress at $\mathrm{OMC}$ of $\sim 100 \mathrm{kPa}$ based on the SSCC, in taking the test on material compacted at $\mathrm{OMC}$ as the base case in the equivalent $M_{\mathrm{R}}$ calculation, it is inherently assumed that suction stresses do not contribute to the stiffness response at or above OMC. For the material tested in this study this was considered reasonable; during CTX testing the OMC specimen suffered volumetric strain which, although within the limits prescribed by Harrigan (2004), likely led to an increase in the degree of saturation (and in dry density) and a decrease in suction stress. Test specimens compacted above OMC were excluded from the sample set owing to their large axial strains (reaching the strain limits prescribed by Harrigan (2004) within three out of a total of 20 test stages), which made them not strictly comparable. As a result, zero suction stresses were assumed in specimens compacted at or wet of optimum for the purpose of back-calculating the suction stress using the equivalent $M_{\mathrm{R}}$ method. It is recommended that, in general, the selection and interpretation of the base case results consider the volumetric strain measured and implied changes in degree of saturation (dry density) that occur during CTX testing. Unfortunately, no matric suction measurements were made on materials after CTX testing.

The $\sigma_{\mathrm{s}}$ values back-calculated from the CTX results are compared with those estimated from the SSCC in Fig. 9. Except for those at a water content of $5.8 \%$ these values are in reasonable agreement especially in view of the assumptions adopted in the methodologies. For materials dry of optimum, a residual water content of $2 \%$ gives a better fit with the back-calculated values than a residual water content of $3 \%$. Further work is required to explore the suction stresses developed at water contents close to optimum.

It should be noted that the suction stress approach by Lu \& Likos (2006) is conceptual only. Although the results appear promising care should be taken in adopting the suction stress method without further research to assess the effects of

(a) the non-uniqueness of the SWRC and the influence of scanning curves (Fredlund et al., 2002)

(b) the difficulty in identifying key elements of the SWRC, for example, the residual water content and inflection point, which needs to be overcome (Otter, 2011)

(c) the accuracy with which water content can be measured; all the work described in this paper was carried out over a very limited range of water content (4 to $8 \%$ ), such that the impact of small changes or errors is amplified

(d) the need for local strain measurement to avoid the very significant effects of bedding on $M_{\mathrm{R}}$ associated with the very high stiffness at low water contents

(e) the non-linear behaviour of pavement materials and the resulting influence of using linear regression analyses to extrapolate $M_{\mathrm{R}}$ values from $\mathrm{OMC}$ when calculating suction stress values from cyclic triaxial values.

\section{CONCLUSIONS}

(a) Values of residual modulus $M_{\mathrm{R}}$ obtained from CTX and HCA tests on the unsaturated clayey sand reported in this paper are broadly in line with the relatively few values reported in the literature for low-plasticity soils of this type. $M_{\mathrm{R}}$ measured at optimum water content, OMC, $(w=7 \%)$, was between $110 \mathrm{MPa}$ and $150 \mathrm{MPa}$, similar to values back-figured from field monitoring in South Africa reported by Gräbe et al. (2005) and by Priest et al. (2010).

(b) $M_{\mathrm{R}}$ increased considerably, from 36 to $467 \mathrm{MPa}$, as the degree of saturation of the specimens decreased from 95 to $45 \%$, when measured in CTX tests and equivalent HCA (SP1) tests carried out with $p_{\mathrm{o}}=q_{\mathrm{cyc}}=30 \mathrm{kPa}$.

(c) The HCA and CTX results reported in this paper in general confirm the large effect of degree of saturation on stiffness previously noted by Otter (2011) and Otter et al. (2015) from very small strain $\left(G_{0}\right)$ resonant column testing. Otter et al. (2015) measured a tripling in $G_{0}$ when the degree of saturation reduced from near saturated to approximately $55 \%(w=5 \%)$. In this study, the stiffness $\left(M_{\mathrm{R}}\right)$ measured in the CTX and HCA 
increased by a factor of about 6 as the degree of saturation decreased to about $45 \%$.

(d) Previous laboratory measurements of resilient modulus have sometimes been made under saturated conditions. These will significantly underestimate the field values likely to be achieved after placement at OMC ( $S_{\mathrm{R}}$ approximately $85 \%$ ) and maximum dry density.

(e) Smaller water content changes, similar to those that might be expected when compacting under construction equipment within given tolerances, also led to significant changes in measured resilient modulus. The average $M_{\mathrm{R}}$ at optimum $(w=7 \%)$ was approximately 1.7 times the near-saturated value (at $w=8 \%$ ).

( $f$ ) Otter et al. (2015) observed a peak in stiffness at a water content of about $5 \%$. The present authors' data are not inconsistent with the idea of a peak at $4.5 \%$ water content, or at least a plateau for materials tested dry of $5 \%$.

(g) At least part of the increase in stiffness $\left(M_{\mathrm{R}}\right)$ measured at lower water contents in the CTX and HCA tests may have been a consequence of reducing strains under constant applied stress paths. The permanent strains, measured after 500 cycles on low-water-content specimens were significantly smaller (approximately $0 \cdot 002 \%$ for $w=4 \%$ and $w=5 \%)$ than at higher water content $(0 \cdot 17 \%$ at $\mathrm{OMC}=7 \%)$.

(h) The suction stress approach shows promise as a means of estimating the matrix stiffness of rail formation materials. However, at this stage the semi-empirical nature of the method and the practical difficulties in determining the SWRC should be borne in mind as potential limitations.

\section{ACKNOWLEDGEMENTS}

The work described in this paper was funded by the Engineering and Physical Science Research Council (EPSRC) through the Programme Grants Track 21 project (EP/H044949/1) and Track to the Future (EP/M025276/1); and Network Rail through the Strategic University Partnership with the University of Southampton in Future Infrastructure Systems. All data supporting this study are openly available from the University of Southampton repository at dx.doi.org/10·5258/SOTON/D0830.

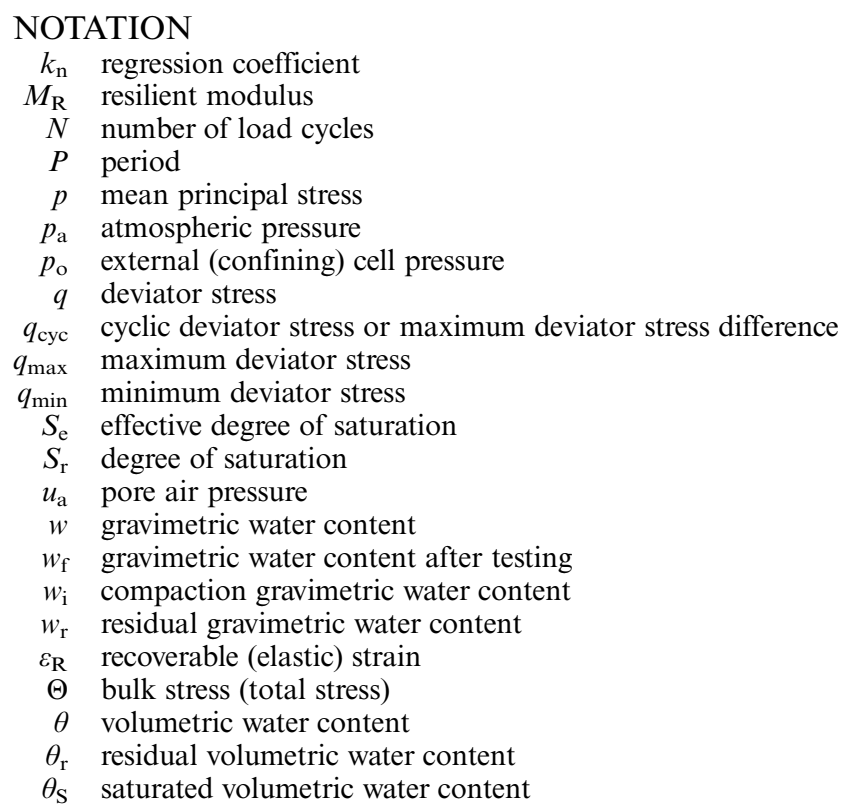

$\sigma$ total stress

$\sigma_{\mathrm{n}}$ net normal stress

$\sigma_{\mathrm{s}} \quad$ suction stress

$\sigma_{1} \quad$ major principal stress

$\sigma_{2}$ intermediate principal stress

$\sigma_{3} \quad$ minor principal stress

$\tau_{\text {oct }}$ octahedral shear stress

$\psi$ total suction

$\psi_{\mathrm{m}} \quad$ matric suction

$\psi_{\mathrm{r}}$ residual matric suction

\section{REFERENCES}

AASHTO (American Association of State Highway and Transportation Officials) (1993). AASHTO guide for design of pavement structures, 4 th edn. Washington, DC, USA: American Association of State Highway and Transportation Officials.

Alonso, E. E., Pinyol, N. M. \& Gens, A. (2013). Compacted soil behaviour; initial state, structure and constitutive modelling. Géotechnique 63, No. 6, 134, https://doi.org/ 10.1680/geot.11.P.134.

ASTM (2007). ASTM D1557-07: Standard test method for laboratory compaction characteristics of soil using modified effort. West Conshohocken, PA, USA: ASTM International.

Baldi, G., Hight, D. W. \& Thomas, G. E. (1988). A reevaluation of conventional triaxial test methods. In Advanced triaxial testing of soil and rock (eds R. T. Donaghe, R. C. Chaney and M. L. Silver), ASTM STP 977, pp. 219-263. Philadelphia, PA, USA: American Society for Testing and Materials.

Brown, S. F. (1996). Soil mechanics in pavement engineering. Géotechnique 46, No. 3, 383-426, https://doi.org/10.1680/ geot.1996.46.3.383.

BSI (2012). BS 1377: Methods of test for soils for civil engineering purposes. London, UK: BSI.

Cary, C. E. \& Zapata, C. E. (2011). Resilient modulus for unsaturated unbound materials. Road Mater. Pavement Des. 12, No. 3, 615-638.

Ceratti, J. A., Gehling, W. Y. \& Nunez, W. P. (2004). Seasonal variation of a subgrade soil resilient modulus in southern Brazil. Transpn Res. Rec. 1874, 165-173.

Cerni, G., Corradini, A., Pasquini, E. \& Cardone, F. (2015). Resilient behaviour of unbound granular materials through repeated load triaxial test: influence of the conditioning stress. Road Mater. Pavement Des. 16, No. 1, 70-88.

Chandler, R. J., Crilly, M. S. \& Montogomery-Smith, G. (1992). A low-cost method of assessing clay desiccation for low-rise building. Proc. Instn Civ. Engrs - Civ. Engng 92, No. 2, 82-89, https://doi.org/10.1680/icien.1992.18771.

ECC (2008). Hymod Prima product specification. C1/323/B, 5th edn. Par, UK: ECC, IMERYS Minerals Ltd. See https:// www.imerys-oilfieldsolutions.com/index.php/ball-clay (accessed 03/04/2019).

Fredlund, D. G. \& Xing, A. (1994). Equations for the soil-water characteristic curve. Can. Geotech. J. 31, No. 3, 521-532.

Fredlund, M. D., Wilson, G. W. \& Fredlund, D. G. (2002). Use of the grain-size distribution for estimation of the soil-water characteristic curve. Can. Geotech. J. 39, No. 5, 1103-1117, https://doi.org/10.1139/t02-049.

Gasparre, A., Hight, D. W., Coop, M. R. \& Jardine, R. J. (2014). The laboratory measurement and interpretation of small-strain stiffness of stiff clay. Géotechnique 64, No. 12, 942-953, https://doi.org/10.1680/geot.13.P.227.

Gräbe, P. J. (2002). Resilient and permanent deformation of railway foundations under principal stress rotation. Southampton, UK: University of Southampton.

Gräbe, P. J. \& Clayton, C. R. (2009). Effects of principal stress rotation on permanent deformation in rail track foundations. J. Geotech. Geoenviron. Engng 135, No. 4, 555-565.

Gräbe, P. J. \& Clayton, C. R. (2014). Effects of principal stress rotation on resilient behavior in rail track foundations. J. Geotech. Geoenviron. Engng 140, No. 2, 04013010.

Gräbe, P. J., Clayton, C. R. \& Shaw, F. J. (2005). Deformation measurement on a heavy haul track formation. In Proceedings of the 8th international heavy haul conference, pp. 287-295. Rio de Janeiro, Brazil: International Heavy Haul Association. 
Harrigan, E. T. (2004). Laboratory determination of resilient modulus for flexible pavement design. NCHRP Res. Results Dig. 285, https://doi.org/10.17226/21960.

Heath, A. C., Pestana, J. M., Harvey, J. T. \& Bejerano, M. O. (2004). Normalizing behavior of unsaturated granular pavement materials. J. Geotech. Geoenviron. Engng 130, No. 9, 896-904.

Hight, D. W. \& Leroueil, S. (2003). Characterisation of soils for engineering purposes. In Characterisation and engineering properties of natural soils (eds T. S. Tan, K. K. Phoon, D. W. Hight and S. Leroueil), pp. 255-362. Lisse, the Netherlands: Swets \& Zeitlinger.

Khoury, N. N. \& Zaman, M. M. (2004). Correlation between resilient modulus, moisture variation, and soil suction for subgrade soils. Transpn Res. Rec. 1874, 99-107.

Lekarp, F., Isacsson, U. \& Dawson, A. (2000). State of the art. I: Resilient response of unbound aggregates. J. Transpn Engng 126, No. 1, 66-75.

Li, D. \& Selig, E. T. (1996). Cumulative plastic deformation for fine-grained subgrade soils. J. Geotech. Engng 122, No. 12, 1006-1013.

Liang, R. Y., Rabab'ah, S. \& Khasawneh, M. (2008). Predicting moisture-dependent resilient modulus of cohesive soils using soil suction concept. J. Transpn Engng 134, No. 1, 3440.

Lourens, J. P. \& Maree, J. S. (1997). Rehabilitation design of high embankments and a coal track formation. In Proceedings of the 6th international heavy haul conference, vol. 1, pp. 57-75. Cape Town, South Africa: International Heavy Haul Association.

Lu, N. \& Likos, W. J. (2006). Suction stress characteristic curve for unsaturated soil. J. Geotech. Geoenviron. Engng 132, No. 2, 131-142.

Lu, N., Godt, J. W. \& Wu, D. T. (2010). A closed-form equation for effective stress in unsaturated soil. Wat. Resour. Res. 46, No. 5 , W05515, https://doi.org/10.1029/2009WR008646.

Mamou, A., Powrie, W., Priest, J. A. \& Clayton, C. R. (2017). The effects of drainage on the behaviour of railway track foundation materials during cyclic loading. Géotechnique 67, No. 10, 845-854, https://doi.org/10.1680/jgeot.15.P.278.

Mamou, A., Priest, J. A., Clayton, C. R. \& Powrie, W. (2018). Behaviour of saturated railway track foundation materials during undrained cyclic loading. Can. Geotech. J. 55, No. 5, 689-697.

Miller, G. A., Li, D. \& Zaman, M. M. (2000). Cyclic shear strength of soft railroad subgrade. J. Geotech. Geoenviron. Engng 126, No. 2, 139-147.

Milne, D. R., LePen, L. M., Thompson, D. J. \& Powrie, W. (2017). Properties of train load frequencies and their applications. J. Sound Vibr. 397, 123-140, https://doi.org/10.1016/j.jsv.2017. 03.006 .

Mitchell, J. K. \& Soga, K. (2005). Fundamentals of soil behavior, 3rd edn. Hoboken, NJ, USA: John Wiley \& Sons Inc.

Muhlhaus, H. B. \& Vardoulakis, I. (1987). The thickness of shear bands in granular materials. Géotechnique 37, No. 3, 271-283, https://doi.org/10.1680/geot.1987.37.3.271.
Nazarian, S., Pezo, R. \& Picornell, M. (1996). Testing methodology for resilient modulus of base materials, Research report 1336-1. El Paso, TX, USA: Center for Geotechnical and Highway Materials Research.

Ng, C. W., Zhou, C., Yuan, Q. \& Xu, J. (2013). Resilient modulus of unsaturated subgrade soil: experimental and theoretical investigations. Can. Geotech. J. 50, No. 2, 223-232, https://doi.org/ 10.1139/cgj-2012-0052.

Network Rail (2005). Business process document NR/SP/TRK/9039 formation treatment. London, UK: Network Rail.

Oda, M. \& Kazama, H. (1998). Microstructure of shear bands and its relation to the mechanisms of dilatancy and failure of dense granular soils. Géotechnique 48, No. 4, 465-481, https://doi.org/10.1680/geot.1998.48.4.465.

Ooi, P. S., Archilla, A. R. \& Sandefur, K. G. (2004). Resilient modulus models for compacted cohesive soils. Transpn Res. Rec. 1874, 115-124.

Otter, L. (2011). The influence of suction changes on the stiffness of railway formation. Southampton, UK: University of Southampton.

Otter, L., Clayton, C. R., Priest, J. A. \& Gräbe, P. J. (2015). The stiffness of unsaturated railway formations. Proc. Insth Mech. Engrs, Part F: J. Rail Rapid Transit 230, No. 4, 1040-1052.

Powrie, W., Yang, L. A. \& Clayton, C. R. (2007). Stress changes in the ground below ballasted railway track during train passage. Proc. Instn Mech. Engrs, Part F: J. Rail Rapid Transit 221, No. 2, 247-261.

Priest, J. A., Powrie, W., Yang, L. A., Gräbe, P. J. \& Clayton, C. R. I. (2010). Measurements of transient ground movements below a ballasted railway line. Géotechnique 60, No. 9, 667-677, https://doi.org/10.1680/geot.7.00172.

Roscoe, K. H. (1970). The influence of strains in soil mechanics. Géotechnique 20, No. 2, 129-170, https://doi.org/10.1680/ geot.1970.20.2.129.

Salour, F. \& Erlingsson, S. (2015). Resilient modulus modelling of unsaturated subgrade soils: laboratory investigation of silty sand subgrade. Road Mater. Pavement Des. 16, No. 3, 553-568.

Santamarina, J. C. (2003). Soil behaviour: the role of particle shape. In Soil behavior and soft ground construction (eds J. T. Germaine, T. C. Sheahan and R. V. Whitman), pp. 25-56. Reston, VA, USA: American Society of Civil Engineers.

Shahu, J. T., Yudhbir, \& Kameswara, R. (2000). A rational method for design of railroad track foundation. Soils Found. - Jap. Geotech. Soc. 40, No. 6, 1-10.

Thom, R., Sivakumar, V., Brown, J. \& Hughes, D. (2008). A simple triaxial system for evaluating the performance of unsaturated soils under repeated loading. Geotech. Testing J. 31, No. 2, 107-114.

Transnet (2006). S410: Specifications for railway earthworks. Johannesburg, South Africa: Transnet Freight Rail (previously Spoornet), a division of Transnet Limited.

Uzan, J. (1985). Characterization of granular material. Transpn Res. Rec. 1022, 52-59. 